\title{
Case Reports in Oncology
}

\section{Use of Eltrombopag in Improving Poor Graft Function after Allogeneic Hematopoietic Stem Cell Transplantation}

\author{
Samip Master Ashish Dwary Richard Mansour Glenn M. Mills \\ Nebu Koshy \\ Division of Hematology and Oncology, Louisiana State University Health Sciences Center \\ Shreveport, LA, USA
}

\section{Keywords}

Acute myeloid leukemia · Stem cell transplantation · Eltrombopag · Allogenic transplant

\begin{abstract}
Eltrombopag is a thrombopoietin agonist and has been used in aplastic anemia and posttransplantation thrombocytopenia. The c-MPL receptor is present on hematopoietic stem cells. There are no reports of eltrombopag utilization for improving poor graft function in the post-transplant setting. Here were report a case of a young female with post-transplant poor graft function as evident from the low absolute neutrophil count, anemia, and thrombocytopenia on day 60 . Eltrombopag was started on day 72 and resulted in improvement in all 3 cell lines. The counts continued to be stable even after eltrombopag was discontinued. The patient tolerated the drug without significant side effects for 1 year.




\section{Introduction}

Eltrombopag is a c-MPL receptor agonist drug [1-3]. Murine studies have shown that the thrombopoietin (TPO)/c-MPL receptor system is present in early hematopoiesis and hematopoietic stem cells (HSCs) [4]. There are few case reports of TPO agonist use in posttransplantation thrombocytopenia. Also, TPO agonist use has been suggested in the management of severe aplastic anemia. Here we report a case of eltrombopag utilization in the treatment of trilineage graft failure.

\section{Case Report}

A 26-year-old female with acute myeloid leukemia developed marrow hypoplasia after 1 cycle of consolidation with high-dose cytarabine. This resulted in severe pancytopenia causing transfusion dependence for both red blood cells and platelets. Following persistence of pancytopenia for almost 5 months, she underwent a matched related (brother) allogeneic hematopoietic stem cell transplant using fludarabine/melphalan conditioning and alemtuzu$\mathrm{mab} /$ tacrolimus as graft versus host disease prophylaxis. The patient had delayed engraftment as the absolute neutrophil count stayed below $1,000 / \mu \mathrm{L}$ (with granulocyte colonystimulating factor support), hemoglobin was less than $8 \mathrm{~g} / \mathrm{dL}$, and the platelet count was less than $20,000 / \mu \mathrm{L}$ even at day 60 . Bone marrow biopsy done on days 30 and 60 as well as at 1 year showed adequate cellularity, no evidence of relapse, and cytogenetics showed normal male karyotype. Chimerism studies showed $100 \%$ donor cells in myeloid lineage (CD33+) at days 30 and 60 . Eltrombopag was started at $50 \mathrm{mg}$ orally daily on day 72 to promote poor graft function. As shown in Figure 1, all 3 cell lines responded. The patient tolerated eltrombopag without any significant side effects. The patient was on eltrombopag for 1 year, and after that, it was stopped. Blood counts continued to be stable after discontinuing eltrombopag.

\section{Discussion}

Binding of TPO to the c-MPL receptor on megakaryocytes is the principal step that results in platelet maturation and release [1]. c-MPL is also expressed on the surface of HSCs [2-4]. Previous studies have shown that the addition of recombinant TPO leads to expansion of the pool of HSCs in culture [4]. In vitro models using knockout mice have shown that deficiency of c-MPL receptor [5, 6] or the TPO ligand leads to a reduced number of HSCs. Eventually, multilineage bone marrow failure develops [7]. These observations suggest that stimulation of c-MPL-signaling pathways may overcome depletion of HSCs and progenitor cells in aplastic anemia. Previous studies were done on cytokines like erythropoietin, and granulocyte colony-stimulating factor in aplastic anemia did not show a benefit because HSCs did not have receptors for these cytokines on them [8].

Romiplostim is a peptide TPO mimetic which activates the TPO receptor by binding to the distal hematopoietic receptor domain. Eltrombopag is a non-peptide TPO mimetic that activates the TPO receptor by binding to the transmembrane domain [9]. While romiplostim 
is given subcutaneously, eltrombopag can be given orally [9]. While romiplostim is only FDA approved for immune thrombocytopenia [10], eltrombopag is FDA approved for immune thrombocytopenia, hepatitis C-related thrombocytopenia, and severe aplastic anemia [11].

Previous studies have shown that both are useful in post-transplantation thrombocytopenia anemia [12-14] and aplastic anemia $[15,16]$. To our knowledge, this is the first case of eltrombopag use for the treatment of trilineage graft failure after allogeneic stem cell transplant [17]. Our case highlights the use of eltrombopag as a very effective medication with minimal side effects to promote poor graft function after allogeneic hematopoietic stem cell transplant. Repeat biopsy done after 1 year did not show any signs of myelodysplasia, recurrent acute myeloid leukemia, or myelofibrosis. Like previous studies on aplastic anemia [6], in our patient, the response continued even after eltrombopag was stopped.

There is evidence that eltrombopag might be stimulating hematopoiesis in noncompetitive activation of c-MPL. In immune thrombocytopenia, TPO levels are at the upper end of average, while in aplastic anemia they are significantly elevated [18]. Eltrombopag binds outside the ligand-binding pocket at the membrane, spanning a region of c-MPL. It activated signaling by JAK-STAT (Janus-associated kinase-signal transducers and activators of transcription) and MAPK (mitogen-activated protein kinase) pathways [19].

Umbilical cord blood is emerging as a promising source of stem cells for allogeneic stem cell transplant, but it is challenged by low stem cell yield. In a previous study done on umbilical cord blood, eltrombopag enhanced expansion of HSCs in vivo and in vitro [5]. Also, eltrombopag favored earlier HSC populations which differed from recombinant TPO [20].

\section{Statement of Ethics}

The authors have no ethical conflicts to disclose.

\section{Disclosure Statement}

The authors have no conflicts of interest to declare.

\section{References}

1 Kaushansky K. Historical review: megakaryopoiesis and thrombopoiesis. Blood. 2008 Feb;111(3):981-6.

2 Kaushansky K, Lin N, Grossmann A, Humes J, Sprugel KH, Broudy VC. Thrombopoietin expands erythroid, granulocyte-macrophage, and megakaryocytic progenitor cells in normal and myelosuppressed mice. Exp Hematol. 1996 Feb;24(2):265-9.

3 Qian H, Buza-Vidas N, Hyland CD, Jensen CT, Antonchuk J, Månsson R et al. Critical role of thrombopoietin in maintaining adult quiescent hematopoietic stem cells. Cell Stem Cell. 2007 Dec;1(6):671-84.

4 Zeigler FC, de Sauvage F, Widmer HR, Keller GA, Donahue C, Schreiber RD et al. In vitro megakaryocytopoietic and thrombopoietic activity of c-mpl ligand (TPO) on purified murine hematopoietic stem cells. Blood. 1994 Dec;84(12):4045-52.

5 Alexander WS, Roberts AW, Nicola NA, Li R, Metcalf D. Deficiencies in progenitor cells of multiple hematopoietic lineages and defective megakaryocytopoiesis in mice lacking the thrombopoietic receptor c-Mpl. Blood. 1996 Mar;87(6):2162-70.

6 Kimura S, Roberts AW, Metcalf D, Alexander WS. Hematopoietic stem cell deficiencies in mice lacking c-Mpl, the receptor for thrombopoietin. Proc Natl Acad Sci USA. 1998 Feb;95(3):1195-200.

7 Geddis AE. Congenital amegakaryocytic thrombocytopenia. Pediatr Blood Cancer. 2011 Aug;57(2):199-203.

8 Gurion R, Gafter-Gvili A, Paul M, Vidal L, Ben-Bassat I, Yeshurun M et al. Hematopoietic growth factors in aplastic anemia patients treated with immunosuppressive therapy-systematic review and meta-analysis. Haematologica. 2009 May;94(5):712-9. 


\section{Case Reports in Oncology}

\begin{tabular}{l|l}
\hline Case Rep Oncol 2018;11:191-195 \\
\hline DOI: 10.1159/000487229 & $\begin{array}{l}\text { (c) 2018 The Author(s). Published by S. Karger AG, Basel } \\
\text { www.karger.com/cro }\end{array}$ \\
\hline
\end{tabular}

Master et al.: Use of Eltrombopag in Improving Poor Graft Function after Allogeneic Hematopoietic Stem Cell Transplantation

9 Kuter DJ. Thrombopoietin and thrombopoietin mimetics in the treatment of thrombocytopenia. Annu Rev Med. 2009;60(1):193-206.

10 Nplate package insert. FDA; 2011

11 Promacta package insert. FDA; 2015.

12 Hartranft ME, Clemmons AB, DeRemer DL, Kota V. Evaluation of romiplostim for the treatment of secondary failure of platelet recovery among allogeneic hematopoietic stem cell transplant patients. J Oncol Pharm Pract. 2017 Jan;23(1):10-7.

13 Poon LM, Di Stasi A, Popat U, Champlin RE, Ciurea SO. Romiplostim for delayed platelet recovery and secondary thrombocytopenia following allogeneic stem cell transplantation. Am J Blood Res. 2013 Aug; $3(3): 260-4$

14 Olnes MJ, Scheinberg P, Calvo KR, Desmond R, Tang Y, Dumitriu B et al. Eltrombopag and improved hematopoiesis in refractory aplastic anemia. N Engl J Med. 2012 Jul;367(1):11-9.

15 Lee JW, Jang JH, Lee SE, Jung CW, Park S, Oh IH. Efficacy and Safety of Romiplostim in Patients with Aplastic Anemia Refractory to Immunosuppressive Therapy: 1-Year Interim Analysis of Phase 2 Clinical Trial. Blood. 2016;128(22):3910.

16 Gill H, Leung GM, Lopes D, Kwong YL. The thrombopoietin mimetics eltrombopag and romiplostim in the treatment of refractory aplastic anaemia. Br J Haematol. 2017 Mar;176(6):991-4.

17 Dyba J, Tinmouth A, Bredeson C, Matthews J, Allan DS. Eltrombopag after allogeneic haematopoietic cell transplantation in a case of poor graft function and systematic review of the literature. Transfus Med. 2016 Jun;26(3):202-7.

18 Emmons RV, Reid DM, Cohen RL, Meng G, Young NS, Dunbar CE et al. Human thrombopoietin levels are high when thrombocytopenia is due to megakaryocyte deficiency and low when due to increased platelet destruction. Blood. 1996 May;87(10):4068-71.

19 Erickson-Miller CL, Delorme E, Tian SS, Hopson CB, Landis AJ, Valoret EI et al. Preclinical activity of eltrombopag (SB-497115), an oral, nonpeptide thrombopoietin receptor agonist. Stem Cells. 2009 Feb; 27(2):424-30.

20 Sun H, Tsai Y, Nowak I, Liesveld J, Chen Y. Eltrombopag, a thrombopoietin receptor agonist, enhances human umbilical cord blood hematopoietic stem/primitive progenitor cell expansion and promotes multi-lineage hematopoiesis. Stem Cell Res (Amst). 2012 Sep;9(2):77-86. 
Master et al.: Use of Eltrombopag in Improving Poor Graft Function after Allogeneic Hematopoietic Stem Cell Transplantation

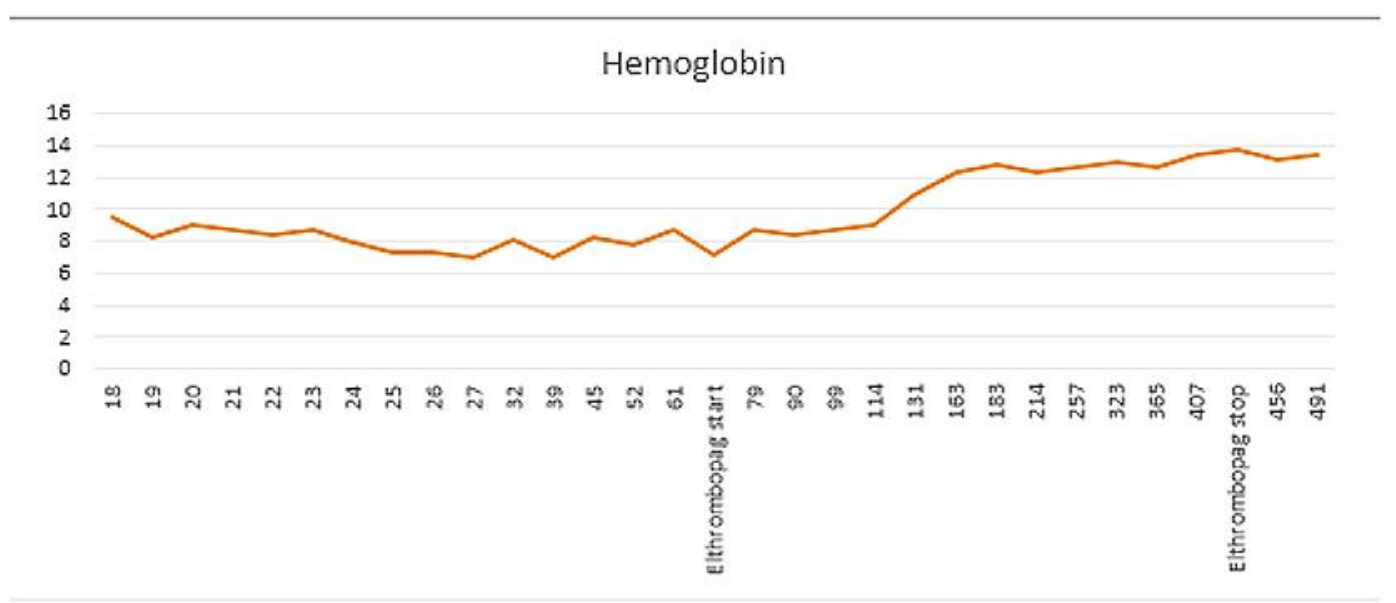

Absolute Neutrophil count

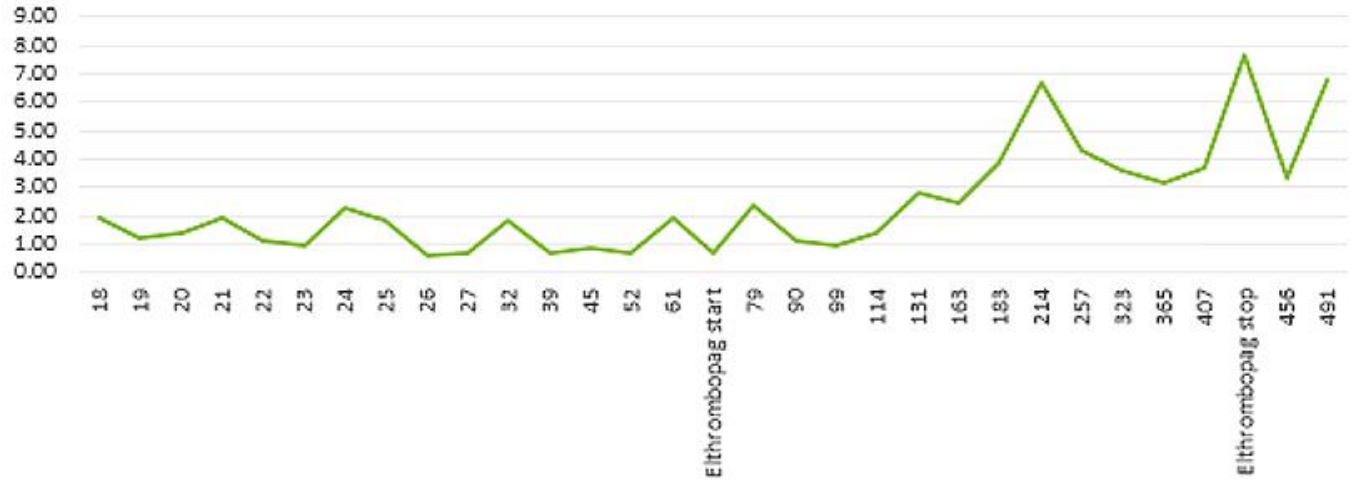

\section{Platelets}

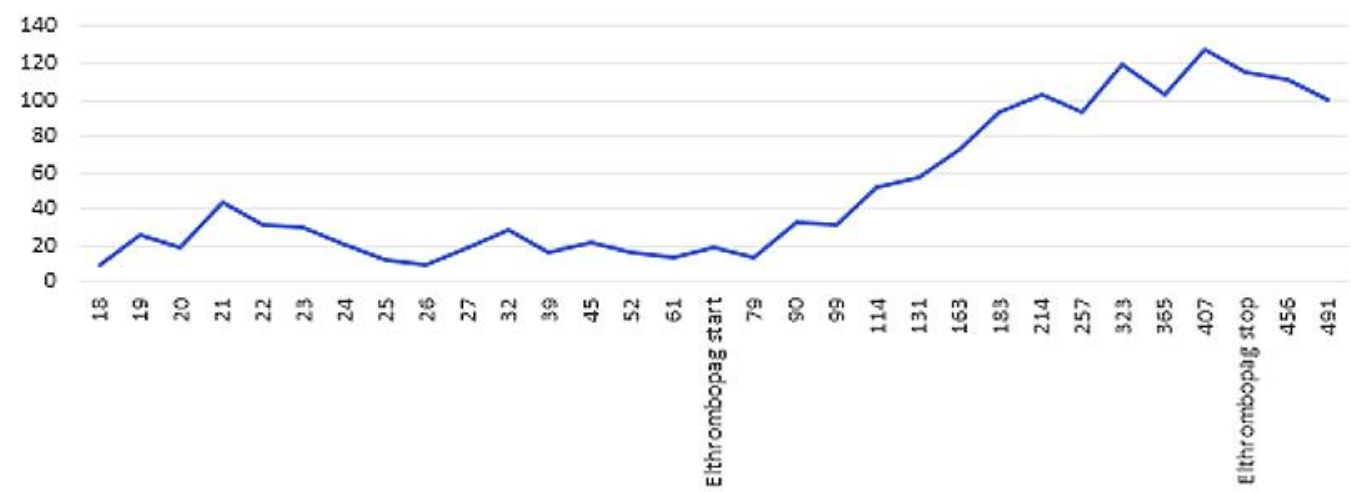

Fig. 1. Three graphs showing the response to eltrombopag. The $x$ axis shows the days after transplant. 